\title{
General Editor's Introduction
}

For more than fifty years, Walter Lippmann was the most respected political journalist in the United States. In 1914, when he was still in his twenties, Lippmann co-founded The New Republic with Herbert Croly and Walter Weyl. He went on to become a serious political philosopher as well as a newspaper columnist, winning the attention (if not always the agreement) of national political leaders from the era of Woodrow Wilson through that of Lyndon B. Johnson. In the history of American political writing, no figure has surpassed Lippmann in combining a scholar's detachment with a newspaperman's immersion in the issues and debates of the day. Long before the term "public intellectual" came into wide currency, Lippmann devoted himself to writing about strenuous topics for a large general audienceand to serving the public good.

Liberty and the News is not, today, among the best-known of Lippmann's books, and the slighting is unfortunate. Here, in three extended essays, Lippmann registered his disillusionment with the political and diplomatic results of the First World War, chiefly as a result of the propagandistic mis- 
information fed by the press to the public. Other commentators analyzed the problem in the simple economic and political terms made familiar by muckraking critics like Ida Tarbell and Upton Sinclair: the newspapers, supposedly, blindly served the interests of their right-wing big-business owners. Lippmann, however, developed a subtler line of reasoning, implicating the readers themselves in the press's deformation and citing numerous pressures, not all of them economic or political, that distorted the news. Above all, Lippmann perceived the crisis of the press as a political one that called into question the viability of democratic government in a large and complex society. Lippmann's proposed solution, although derided by some as elitist, helped to establish standards of objective factual reporting that became the norm at the most respected newspapers and other newsgathering institutions for decades to come.

The James Madison Library in American Politics will include the work of many political journalists, and it seems appropriate for Lippmann to head the list. It also seems appropriate to reissue the book in which he confronted most directly his own profession-elucidating his complaints but expressing his abiding hope that the public could yet receive the kind of accurate information on which any working democracy relies.

It is all the more urgent that Lippmann's criticisms be reconsidered today. Lippmann wrote of 
a very different press corps in a much simpler era. The proliferation of information sources after the advent of the Internet and cable television; the rise of the frenzied round-the-clock news cycle; the consequent decline in the subscription base for newspapers; the elimination, during the 1980 s, of the Fairness Doctrine, which in one form or another had governed the public airwaves since the 1920s-all have profoundly altered journalism of every variety, especially political journalism. A rash of scandals over offenses ranging from plagiarism to new, insidious forms of government propagandizing has caused crises of confidence in newsrooms all across the country. But these current developments have simply enlarged what Lippmann identified long ago as "the pseudo-environment of reports, rumors, and guesses" that comes between people and the truth. His basic criticisms and analysis of that pseudo-environment are as pertinent as ever.

In his new foreword, Ronald Steel, the distinguished historian and author of an outstanding biography of Lippmann, places Liberty and the News in the context of Lippmann's career and highlights the gap between harsh reality and what Lippmann would later call "the original dogma of democracy." Sidney Blumenthal, the veteran journalist who also served in the Clinton White House, picks up in his afterword on Lippmann's concerns and indicts the reporting of political 
news during the George W. Bush presidency as a betrayal of Lippmann's ideal of objectivity. Both essays show that, whatever one's personal political beliefs may be, the existence of the press as a check on official power, the so-called Fourth Estate of American democracy, is by no means secure. Vulnerable to many forces, from inside as well as outside their profession, American reporters, editors, and publishers must constantly assess how well they are meeting their basic responsibilities to inform a democratic citizenry. Indeed, it appears that now as much as in 1920, and maybe more, the press needs to learn what those basic responsibilities are. Liberty and the News is a good place to start.

Sean Wilentz

$x$ General Editor's Introduction 